\title{
A POLÊMICA EM TORNO DA LITERATURA INDIANISTA NO INSTITUTO HISTÓRICO E GEOGRÁFICO BRASILEIRO 1838-1860*
}

\author{
Thiago Granja Belieiro ${ }^{1}$ \\ ${ }^{1}$ Doutor em História pela Universidade Estadual Paulista - Unesp, Assis, SP. Professor do curso de História da \\ Universidade do Oeste Paulista - UNOESTE. E-mail: thiagobeli@hotmail.com
}

\section{RESUMO}

Este artigo insere-se no campo dos estudos históricos culturais. Assim, a análise histórica é aqui empregada com o objetivo de compreender o fenômeno artístico literário, a saber, o Indianismo Romântico do século XIX. Desse modo, o Indianismo é visto como uma Invenção Histórica, ou seja, é fruto de um trabalho e de um projeto consciente dos escritores no sentido de criação de uma cultura e uma literatura nacional, tendo o índio como figura central. Assim, vai-se analisar o papel do Instituto Histórico e Geográfico Brasileiro nesse processo de Invenção Histórica. O IHGB foi o palco principal de uma acalorada contenda sobre a viabilidade de se escrever uma literatura tendo o índio como figura central, mostrando as diferentes tomadas de posição dos intelectuais do período acerca da Literatura Indianista.

PALAVRAS-CHAVE: História. Literatura. Indianismo.

\section{POLICY AROUND INDIAN LITERATURE IN THE BRAZILIAN HISTORICAL AND GEOGRAPHICAL INSTITUTE 1838-1860}

\begin{abstract}
This article is within the field of historical and cultural studies. Thus, the historical analysis employed here aims at understanding the literary artistic phenomenon, namely the XIX century Romantic Indianism. In this aspect, Indianism is seen as a historical invention, that is, it arises involuntarily within the European thought and within the Romantism aesthetic precepts, which later became the result of writers' conscientious work and project in order to create both a national culture and literature, having the Indian as its central figure. Thus, the role of the Instituto Histórico e Geográfico Brasileiro (Brazil's Historical and Geographical Institute - IHGB) is analyzed in this historical invention process. Furthermore, the IHGB was the main stage of a fierce argument on the viability of making literature having the Indian as its central figure, showing the different positions the intellectuals of the period held about the Indianist Literature.
\end{abstract}

Keywords: History. Literature. Indianism.

\section{POLÍTICA ALREDEDOR DE LA LITERATURA INDIA EN EL INSTITUTO HISTÓRICO Y GEOGRÁFICO BRASILEÑO 1838-1860}

\section{RESUMEN}

Este artículo está en el campo de los estudios históricos culturales. Así, el análisis histórico se emplea aquí para comprender el fenómeno artístico literario, a saber, el romanticismo del siglo XIX. Por lo tanto, el indigenismo es visto como una invención histórica, es decir, es el resultado de un trabajo y un proyecto consciente de los escritores en el sentido de crear una cultura y literatura nacional, con el indio como figura central. Por lo tanto, analizaremos el papel del Instituto Histórico y Geográfico de Brasil en este proceso de invención histórica. El IHGB fue el escenario principal de una disputa acalorada sobre la viabilidad de

\footnotetext{
${ }^{*}$ A pesquisa contou com o financiamento do CNPq.
} 
escribir una literatura con el indio como figura central, mostrando las diferentes posiciones de los intelectuales de la época sobre la literatura indigenista.

PALABRAS CLAVE: Historia. Literatura, Indianismo

\section{INTRODUÇÃO}

[...] este artigo, que escrevemos não para defender o Sr. Ig, pois ele não precisa do nosso fraco apoio, mas simplesmente para ajuda-lo a rebatar os pretenções da enfatuada confraria litterária, que tem arrogado a si o direito de dar e tirar reputações.

Sr. Omega (PINHEIRO GUIMARÃES) $1856 .{ }^{1}$

O texto acima, escrito dentro da polêmica em torno do poema indianista de Gonçalves de Magalhães, evidencia o papel assumido pelo Instituto Histórico e Geográfico Brasileiro não só na contenda em torno da Confederação dos Tamoios, mas também e principalmente em todo o processo de invenção histórica do Indianismo Literário.

$\mathrm{Na}$ busca de nacionalidade, de uma tradição histórica, de um herói e de um mito nacional, o índio vai se tornar o personagem central. Sua figura, suas tradições e mitos, sua língua e costumes vão ser amplamente utilizados pelos literatos em suas obras ficcionais. Essa utilização vai se constituir numa invenção histórica, a invenção do Indianismo Literário.

Com efeito, a partir de 1838, com a criação do Instituto Histórico e Geográfico Brasileiro, praticamente a única instituição cultural erudita da Corte, o Movimento Romântico passou a contar com um local privilegiado para seu desenvolvimento e propagação. O Instituto, que congregava em seus quadros, literatos com Gonçalves Dias e Gonçalves de Magalhães, entre outros, passa a funcionar como uma verdadeira confraria literária, onde posições estéticas eram debatidas e consagradas.

Essa tendência se acentua na década de 50 do século XIX, quando o Instituto passa para a

\footnotetext{
1 Artigo de Pinheiro Guimarães, assinado com o pseudônimo Omega, publicado no Diário do Rio de Janeiro em 1856, a respeito da polêmica sobre a Confederação dos Tamoios, que será analisada mais adiante. Ig é o pseudônimo assumido por José de Alencar na polêmica.
}

tutela do Estado Imperial, e quando o Imperador passa a ser assíduo freqüentador do IHGB. Neste momento o Imperador dom Pedro II passa a interferir nos projetos culturais do Instituto, seja na proposição de temas de pesquisa, seja no apoio a literatos ou mesmo se engajando em discussões literárias para defender certas posições estéticas adotadas pelos escritores membros do Instituto Histórico e Geográfico Brasileiro.

É assim que a invenção histórica do Indianismo Literário torna-se um projeto oficial de Estado, ou seja, surge e se consolida enquanto movimento literário dentro do Instituto Histórico, com o apoio direto do Imperador e do Estado Imperial. E mais, O IHGB produz um vasto conhecimento sobre os índios, torna-se um dos palcos principais de uma acirrada discussão em torno do índio como símbolo da nacionalidade, ao mesmo tempo em que estimula e legitima uma produção literária tendo o indígena como figura central.

Segundo Pinheiro Guimarães, o Instituto Histórico assumiu papel de legítima confraria literária, uma vez que congregava entre seus membros importantes escritores como Gonçalves de Magalhães, Gonçalves Dias, e outros de menor importância no Indianismo, como Manuel de Araújo Porto Alegre, Domingos Sales Torres Homem entre outros, congregando ainda boa parte da elite letrada do período, como médicos, engenheiros, políticos e funcionários do Estado Imperial.

Além disso, segundo Pinheiro Guimarães, - IHGB arrogou a si o direito de dar e tirar reputações literárias, ou seja, o Instituto legitimava e apoiava aqueles escritos literários que estivessem de acordo com suas pretensões dentro do projeto de invenção histórica do indianismo levada a cabo pelos seus membros.

Para compreender a relação do Instituto Histórico com a criação literária do período romântico, três fatores são fundamentais. Em primeiro lugar, o IHGB era praticamente a única instituição cultural da Corte, palco da invenção histórica do Indianismo Literário. Assim, o Instituto possuía uma hegemonia na produção erudita e cultural, uma vez que boa parte dos 
produtores de bens culturais, entre eles os literatos, eram membros ativos do Instituto, como o caso de Gonçalves de Magalhães e Gonçalves Dias. Com isso, o Instituto torna-se o centro de irradiação de um projeto Imperial de formação de uma autonomia cultural, centrada principalmente na questão da nacionalidade literária.

Em segundo lugar, temos de levar em conta a intrínseca relação do IHGB com o campo de poder. Sendo uma instituição cultural subordinada ao Estado Imperial, sua produção erudita vai estar sujeita às exigências do campo de poder. Assim, temos um campo literário em formação atuante dentro do IHGB, evidenciando a relação entre os campos de poder e o literário, bem como a subordinação estrutural deste campo em relação aquele. Desta forma, percebemos a vinculação deste grupo de escritores a esse projeto de Estado, que produziam de acordo com as exigências deste projeto de invenção histórica. Em terceiro lugar, está o papel que o IHGB possui enquanto configurador de um campo de possíveis estéticos através de seus estudos sobre o índio. ${ }^{2}$

\section{MÉTODOS}

Neste texto analisaram-se artigos escritos por membros e não membros do Instituto Histórico e Geográfico Brasileiro a respeito da questão indígena, sobretudo em relação à viabilidade de se escrever uma literatura onde o índio é o tema central. Esses artigos mostram o grau de consciência que tinham os produtores de bens culturais acerca do projeto de invenção histórica do Indianismo Literário, mostrando as posições no campo literário e de poder, bem como as tomadas de posição estética dos intelectuais envolvidos, ao mesmo tempo em que evidenciam o nível de subordinação estrutural entre os campos literário e de poder. Outros textos a serem utilizados são artigos publicados no século XIX em jornais e revistas do período,

\footnotetext{
${ }^{2}$ Segundo o sociólogo Pierre Bourdieu, na ciência das obras de arte são três as operações necessárias e que são necessariamente interligadas. Em primeiro lugar, analisar a posição do campo literário em relação ao campo de poder. Em segundo lugar, está a necessidade de se analisar a estrutura interna do campo literário, ou seja, perceber a estrutura de relações objetivas entre as posições que aí ocupam indivíduos ou grupos. Em terceiro lugar, está a análise da gênese do habitus dos ocupantes dessas posições, ou seja, os sistemas de disposições culturais que façam com que determinados autores assumam determinadas posições estéticas. Assim, dentro do Instituto Histórico e Geográfico Brasileiro, ocorreu a formação de um campo de possíveis estéticos, ou seja, nele se criou possibilidades de criação literária de acordo com os critérios acima. (BOURDIEU, 1996)
}

consultados diretamente em arquivos públicos ou que foram publicados em coleções de documentos históricos. Desse modo, o presente texto apresenta uma pesquisa histórica realizada quase que totalmente com fontes primárias. Com isso, a metodologia empregada é a de análise de fontes históricas.

\section{RESULTADOS}

O Estado Imperial tinha como uma das suas preocupações fundamentais, a elaboração de uma identidade nacional, identidade essa que passava necessariamente pelo campo cultural. Nesse sentido, o Instituto Histórico e Geográfico Brasileiro, teve papel central nesse processo de edificação dessa identidade, que passava pelos estudos históricos, geográficos, etnográficos e literários realizados pelos membros ativos do Instituto. Nesse texto, investigamos a acalorada discussão em torno da viabilidade de alçar o índio como figura central do movimento Romântico brasileiro, isto é, em tornar o índio personagem central da criação literária ao mesmo tempo em que o indígena tomava a posição de verdadeiro herói nacional. Contudo, as posições dos intelectuais do Império eram bastante divergentes acerca do tema.

Assim, temos autores que se colocam contra, como o caso do historiador Varnhagen, ao mesmo tempo, outros são decisivamente a favor, como o Imperador dom Pedro II, atuante participante da contenda indianista. Outros, como José de Alencar, que mesmo não fazendo parte da confraria literária que era o IHGB, participou da contenda atacando o poema de Gonçalves de Magalhães. Contudo o fez atacando a forma do poema e não seu conteúdo, do qual concordava e que veio partilhar em suas obras indianistas.

Assim, notamos que o grupo romântico hegemônico era aquele formado pelos membros diretos do Instituto Histórico. Outros grupos, como o da chamada "geração boêmia" formada por escritores e intelectuais mais afastados do grupo do IHGB, eram aqueles que questionavam e criticavam a forma oficial que a literatura romântica vinha tomando através de sua inserção no campo de poder através do Instituto Histórico. Evidentemente que o posicionamento dos intelectuais favoráveis ao projeto acabou por se revelar a vencedora da contenda, algo facilmente constatável na literatura que se produziu tendo o indígena o personagem central. Mesmo assim, a discussão em torno do tema é de uma riqueza 
sem igual para a compreensão das relações entre a Literatura e a Sociedade, tal como preconizada por Antonio Candido.

\section{DISCUSSÃO}

A revista Nitheroy, revista brasiliense de Sciencias, Lettras e Artes, publicada em Paris em 1836, por Gonçalves de Magalhães e Manuel Araújo Porto Alegre, entre outros, com o epíteto "tudo pelo Brasil e para o Brasil" fora considerada um dos marcos inaugurais do Romantismo brasileiro. O periódico, do qual se publicou apenas dois números, propunha-se discutir questões relativas ao país e seus desenvolvimentos nos diversos campos culturais, como as ciências e as artes.

Gonçalves de Magalhães publicou ensaio no primeiro número da revista sob o título: Ensaio sobre a História da Litteratura do Brasil. Neste ensaio Magalhães evidencia o papel da literatura na configuração da nacionalidade de qualquer povo, segundo ele:

$$
\begin{aligned}
& \text { A litteratura de um povo } \\
& \text { é o desenvolvimento do } \\
& \text { que ele tem de mais } \\
& \text { sublime nas idéias, de } \\
& \text { mais philosophico no } \\
& \text { pensamento, e de mais } \\
& \text { bello na Natureza, é o } \\
& \text { quadro animado de suas } \\
& \text { virtudes, e de suas } \\
& \text { paixoens, o despertar de } \\
& \text { sua gloria, e o reflexo } \\
& \text { progressivo de sua } \\
& \text { intelligencia } \\
& \text { (MAGALHÃES, 1836, p. } \\
& \text { 135). }
\end{aligned}
$$

Assim, o autor lamenta o tão parco desenvolvimento que a literatura pátria tinha conseguido até ali, clamando para que os escritores brasileiros se esforçassem nesse desenvolvimento. Neste momento histórico de formação do campo literário romântico no Brasil, é patente o afã de nossa literatura em mostrar-se nacional e nacionalista, sobretudo nos temas e nas formas pictóricas de representação da natureza e também das populações primitivas do país. Esse afã tornar-se-á verdadeiro projeto de Estado a partir de 1849 quando o Imperador dom Pedro II passa a frequentar assiduamente o IHGB, tomando a frente do projeto de invenção histórica do Indianismo Literário.

Sobre esses pontos, Gonçalves de Magalhães desenvolve sua argumentação sobre o desenvolvimento das letras pátrias e pergunta: "Pode o Brasil inspirar a imaginação de seus poetas? $E$ os seus indígenas cultivaram porventura a poesia?".

Com respeito à primeira questão, Magalhães cita os viajantes que descreveram o país, levando seus relatos e suas impressões sobre o Brasil para toda a Europa. Segundo o autor, esses viajantes enalteceram o país e suas belezas em seus relatos. Assim, à primeira questão proposta o autor responde dizendo que grandes autores da literatura tiveram como inspiração o céu de sua pátria, a beleza de sua natureza e conclui: "com tão felizes disposições da natureza o Brasil necessariamente inspirar devera seus primeiros habitadores".

Com isso, Magalhães chega ao ponto em que mais nos interessa em seu artigo. $O$ autor acredita e defende a idéia de que nossos habitantes primitivos tinham grande propensão para a poesia e para a música. Segundo ele, com uma natureza tão bela e pródiga "os brasileiros músicos e poetas nascer deviam". Assim, o autor enaltece os indígenas, construindo sobre eles uma representação indianista. Na continuação do ensaio, Magalhães questiona se duvidam de que eram os índios músicos e cultivadores da poesia:

Quem o duvida? Elles o foram, elles ainda o são. Por alguns escriptos antigos sabemos que varias tribus índias pelo talento da música, e da poesia se avantajavam. Entre todas, os Tamoyos, que mais perto da costa habitavam, eram tambem os mais talentosos; em suas festas, e por ocasião de combates, inspirados pelas scenas que os torneavam, guerreiros hynos improvisavam, com que acendiam a coragem nas almas dos combatentes, ou cantavam em coros alternados de musica e dansa hymnos herdados dos seus maiores. (MAGALHÃES, 1836, p. 135).

Enaltecendo os indígenas, Magalhães ainda que pouco explícito sobre suas idéias a respeito da literatura, ou sobre o programa que 
os escritores deveriam seguir em suas produções, nos dá pistas para a compreensão do programa literário a que deveriam se dedicar os escritores tupiniquins. O autor torna evidente ainda sua posição frente ao projeto de invenção histórica do Indianismo Literário.

Em primeiro lugar, o país e sua natureza pródiga deveria servir de inspiração a nossos escritores, assim como Virgílio e Horácio buscaram inspiração na sua península, e Homero na sua Grécia, o Brasil grande inspiração causaria aos nossos poetas e escritores.

Em segundo lugar, ainda que não fale explicitamente, os nossos índios teriam um lugar importante dentro do desenvolvimento das letras do país. Sendo eles mesmos músicos e poetas, já teriam garantido seu lugar de importância em nossas artes. Com isso Magalhães coloca a origem da criação artística do país num tempo passado remoto e ideal, atribuindo aos índios essa originalidade. Ainda, tendo todas essas qualidades, naturalmente que deveriam ser eles motivo de inspiração para a criação artística e literária. E ainda, mereceriam ser incorporados à população, seja de forma prática ou simbólica como faria a literatura.

Desta forma, construindo uma representação indianista ${ }^{3}$ sobre os índios, Magalhães abre um caminho dentro das possibilidades de criação artística, ou seja, o autor abre um campo de possíveis estéticos para nossos escritores tendo o índio no centro. E mais, Magalhães torna evidente sua posição frente ao projeto de invenção histórica do Indianismo Literário.

Em 1844 o Instituto Histórico e Geográfico Brasileiro propõe um programa para dissertação com o tema: "Como se deve escrever a história do Brasil?". A idéia era a de que algum estudioso apresentasse o melhor programa metodológico para a escrita da história do país.

Em 1847 é premiada a dissertação vencedora: Como se deve escrever a história do Brasil. O vencedor, o naturalista alemão Carl F.P. von Martius, que já havia escrito importante livro de viagens sobre o país, e que mesmo na Europa continuava interessado no Brasil e nos seus assuntos, era sócio correspondente do IHGB.

\footnotetext{
${ }^{3}$ Nesse artigo vai-se utilizar o termo representação indianista para indicar o tipo de representação que faz apologia dos índios nos mais diversos aspectos e representação não indianista para indicar as representações que depreciam a imagem do mesmo. Sendo assim, essas representações vão atuar na configuração do campo de possíveis estéticos do indianismo.
}

O seu programa metodológico para a escrita da história do país propunha o estudo conjunto dos três elementos humanos que concorreram para a formação do povo brasileiro, o índio, o negro e o branco. Portanto, a originalidade de seu programa está na incorporação nos estudos históricos referentes ao Brasil, o estudo das duas raças comumente negligenciadas, o índio e o negro.

Neste sentido, o índio é visto como parte integrante e essencial nessa forma de se escrever a história do país. Para Martius, a mistura das três raças constituintes do povo brasileiro, irá formar um novo povo, formando uma nação nova e maravilhosamente organizada, uma vez que mesclando as diferentes raças, teríamos a formação de um povo homogêneo e unido. Com isso, para a escrita da história do país, o estudo da origem e formação dos três diferentes povos seria essencial. Diz o autor:

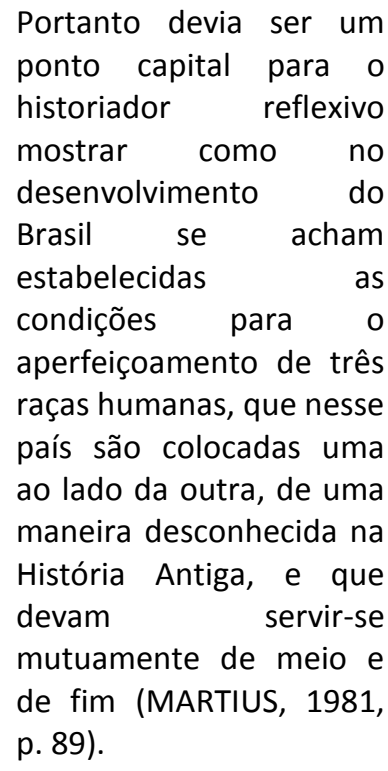

Assim, fica explicitado o programa metodológico do naturalista Martius, que possui uma originalidade singular nesse momento histórico ao propor esse método para o estudo da história do país. Dessa forma, esse programa metodológico teve alguma influência nas tomadas de posição estética dos escritores.

Sobre os povos indígenas, que Martius havia tido contanto em suas andanças pelo Brasil, construindo sobre estes representações indianistas que configuram um campo de possíveis estéticos, sobretudo do índio anterior ao contato com os brancos, o autor defende entusiasmaticamente o estudo de suas origens, para ele o historiador:

[...] igualmente deveria encarregar-se da tarefa 
de investigar

minuciosamente a vida e

a história do

desenvolvimento dos

aborígines americanos e

estendendo suas

investigações além do

tempo da conquista,

prescutinará a história

dos habitantes primitivos do Brasil, história que por ora não dividida em épocas distintas, nem oferecendo monumentos visíveis, ainda esta envolta em obscuridade, mas que por essa mesma razão excita sumamente nossa curiosidade. (MARTIUS, 1982, p. 91)

O objetivo de Martius com essas proposições acerca do estudo da história indígena é corroborar a tese de João Maurício Rugendas ${ }^{4}$ e por ele adotada, segundo o qual os índios eram restos de uma grande nação próspera e desenvolvida que havia decaído ao longo da história, levando os indígenas ao estado degradante em que se encontravam no século XIX.

Com isso, para o autor, os índios não estavam em estado primitivo, e sim em estado decadente, degenerado de vida. Para ele, os cronistas que escreveram sobre os índios estavam iludidos por uma forma incorreta de considerar os mesmos, segundo o autor:

[...] consideravam-se os aborígines do Brasil como uma amostra do desenvolvimento possível do homem privado de qualquer revelação divina, e dirigido na vereda de suas necessidades e inclinações físicas unicamente por sua razão instintiva. Enfeitado com as cores de uma filantropia e Filosofia enganadora,

consideravam este estado

\footnotetext{
${ }^{4}$ No seu livro de viagens escrito acerca do Brasil, tendo contato com diferentes tribos indígenas, Rugendas elabora essa teoria para explicar a diferença que notava entre tribos isoladas e tribos aldeadas, estando as segundas geralmente em estado degradante, e as primeiras geralmente com condições melhores de vida.
}

como primitivo do homem; procuravam explicá-lo, e dele derivaram os mais singulares princípios para o Direito Publico, Religião e a História (MARTIUS, 1982, p. 91).

O autor refere-se aí à filosofia do genebrino Jean Jacques Rousseau, que queria ver no indígena brasileiro o homem primitivo, próximo à natureza. Para Martius, essa forma de ver o índio impedia que se entendesse a real condição desses povos. Para ele:

Investigações mais
aprofundadas porém
provaram ao homem
desprevenido que aqui
não se trata do estado
primitivo do homem, e
que pelo contrário o
triste e penível quadro,
que nos oferece o actual
indígena brasileiro, não é
senão o residuun de uma
muito antiga, posto que
pedida história
(MARTIUS, 1982, p. 92).

Desta forma, para defender seu programa metodológico e seu ponto de vista acerca do estado de civilização dos indígenas, Martius escreve além da dissertação sobre a história, uma pequena dissertação com o título: $O$ Estado de Direito entre os autóctones do Brasil. Neste texto, Martius elabora mais sistematicamente a teoria de Rugendas, segundo a qual os índios observados vivendo nas matas brasileiras eram restos de uma grande e única florescente civilização indígena que havia degenerado e decaído até o estagio atual em que o autor os encontrou.

Vejamos as palavras do naturalista Martius:

[...] esse triste estado do selvagem, sem dúvida, não é o do primitivo em que se acha a humanidade americana, é uma degeneração e um abaixamento. Muito além e separado por uma obscuridade de milênios, está um passado mais nobre e que escassíssimos restos 
ainda permitem adivinhar (MARTIUS, 1982, p. 66)

Portanto, para Martius o indígena embora sendo um ser degenerado e decadente em sua civilização, ainda sim ele é considerado o herdeiro de uma grande civilização perdida. Com isso, o autor acaba por construir uma representação indianista acerca dos índios. Contudo, não é o estado atual do índio que recebe este tratamento, e sim aquele índio daquele passado de glórias imaginado pelo autor.

Assim, além de construir essa representação enaltecedora dos indígenas brasileiros, Martius ao propor em seu método de investigação histórica, a incorporação dos indígenas como parte integrante da nação, propondo ainda que se faça estudos históricos sistemáticos a seu respeito, faz com que os povos indígenas ganhem importância não só dentro dos estudos históricos, mas também dentro da idéia de nação que se queria construir. Naturalmente, suas idéias vão contribuir nas tomadas de posição estéticas dos escritores indianistas, contribuindo enfim para a ascensão do indígena como herói da nacionalidade.

O historiador Francisco Adolfo de Varnhagen, que se enveredou por diversos campos de conhecimento, entre eles o literário, escreve em 1847 o "Ensaio Histórico sobre as Letras no Brasil", publicando-o em 1850 dentro de seu compendio literário o Florilégio da Poesia Brazileira.

Neste ensaio, Varnhagen procura investigar a história literária do país desde o período colonial, elecando autores, correntes e obras. Neste caminho, o autor expõe algumas idéias sobre a literatura indianista produzida ainda no século XVIII, com as obras de Basílio da Gama e de José de Santa Rita Durão, respectivamente o Uruguay e o Caramuru. Ainda, o autor especula sobre a relação dos índios com a poesia e a oratória. Desse modo, nesse ensaio fica evidente a posição do historiador frente ao projeto de invenção histórica do Indianismo Literário, influenciando com isso as tomadas de posição estéticas contrárias a esse projeto.

Varnhagen tinha uma concepção histórica ligada ao nosso passado colonial. Para ele a civilização brasileira era uma continuidade, uma herdeira da civilização portuguesa nos trópicos. ${ }^{5}$

\footnotetext{
${ }^{5}$ Segundo Nilo Odália, Varnhagen procura ressaltar o papel do Estado na formação da nação e do homem branco brasileiro. Desta maneira "São momentos necessários de um projeto político de
}

Assim, sua visão historiográfica estava carregada de eurocentrismo, o que acarretava certo preconceito com relação aos exotismos brasileiros, sobretudo no concernente aos indígenas. Para o autor, os índios eram seres decadentes, e para eles a solução era o aldeamento e a catequização como forma de destruir sua cultura e incorporá-los a civilização brasileira.

Mas é na argumentação sobre a busca de originalidade da literatura brasileira, que Varnhagen expõe mais explicitamente sua posição acerca da Literatura Indianista. Segundo ele: "Deus o fade bem, para que os poetas, em vez de imitarem o que lêem se inspirem da poesia que brota com tanta profusão do seio do próprio paíz, e sejam antes de tudo originais, americanos". (VARNHAGEN, 1853, p. 15). Assim Varnhagen propõe que seja original nossa literatura, mas, no entanto, faz ressalvas acerca desta originalidade. Para ele o poeta:

$$
\begin{aligned}
& \text { [...] que, para buscar } \\
& \text { originalidade, } \\
& \text { despresasse todos os } \\
& \text { elementos da civilização, } \\
& \text { todos os preceitos da } \\
& \text { religião, que nos } \\
& \text { transmittiram nossos } \\
& \text { pais. Não será um } \\
& \text { engano, por exemplo, } \\
& \text { querer produzir efeito, e } \\
& \text { ostentar patriotismo, } \\
& \text { exaltando as ações de } \\
& \text { uma caterva de canibaes, } \\
& \text { que vinha assaltar uma } \\
& \text { colônia de nossos } \\
& \text { antepassados só para os } \\
& \text { devorar? (VARNHAGEN, } \\
& \text { 1853, p. 15-16). }
\end{aligned}
$$

Desta forma, para Varnhagen, a literatura brasileira não poderia buscar sua originalidade narrando os feitos e o modo de vida de tribos indígenas, que para ele não passavam de canibaes que dificultavam a empresa colonial.

Para o historiador, a poesia brasileira deve nutrir-se na natureza nova e virgem, apoiando-se no descritivo desta natureza para produzir uma grande literatura. Deve ainda, louvar a Deus e promover a civilização: "deu-nos

Nação, que se deseja ver implantado no presente e no futuro, e solidamente alicerçado e alimentado na seixa que o pode legitimar: o passado colonial. Seu mergulho na nossa história colonial é um gesto de criação e proteção, visando fazer dela surgir uma nação branca e européia, coerente com a paisagem tropical civilizada pelo homem branco europeu". (ODÁLIA, 1979, p. 14) 
Deus a inspiração poética para o louvarmos, para o magnificarmos pela religião, para promover a civilisação e exaltar o animo a acções generosas" (VARNHAGEN, 1853, p. 15-16).

Sobre $O$ Caramuru, de José de Santa Rita Durão, um dos primeiros poemas de temática indianista publicado no final do século XVIII, Varnhagen elogia a elegância e a beleza do poema. Acredita que o poema chegará um dia a ser popular no país, mas a respeito da temática e do herói do poema Varnhagen assim se pronuncia: “(...) nelle o poeta só por seu gênio conseguiu fazer heroe um individuo que estava longe de o poder ser". (VARNHAGEN, 1853, p. 16). Está clara, portanto, a posição do historiador frente ao projeto de invenção do Indianismo Literário.

Com semelhantes opiniões acerca do caráter dos povos indígenas do Brasil, naturalmente que Varnhagen não concordava com a incorporação dos índios na população nacional, muito menos serviriam os índios como inspiração para uma literatura que queria pintarse com as cores do país e tornar herói o elemento humano primitivo da nação.

Para concluir suas idéias acerca dos indígenas, Francisco Adolfo de Varnhagen concorda que sua pintura dos índios feita em sua obra é bem pouco lisonjeira. Em palavras explícitas, Varnhagen condena os poetas e os filósofos que querem ver no primitivo a maior felicidade dos homens. Segundo o autor: "À vista do esboço que traçamos, sem nada carregar as cores, não sabemos como haja ainda poetas, e até filósofos que vejam no estado selvagem a maior felicidade do homem; [...]". (VARNHAGEN, 1998, P. 53).

Sobre os poetas ironizados por Varnhagen estavam aqueles que dividiam com ele as sessões e os trabalhos dentro do Instituto Histórico, como Gonçalves Dias e Gonçalves de Magalhães, a quem chamava de patriotas caboclos. Já o filósofo é o maior responsável pelos conceitos formadores do Indianismo, JeanJacques Rousseau. Sobre este, Varnhagen ironiza também sua filosofia. Diz Varnhagen: "O próprio filósofo de Genebra, apesar de suas paradoxais simpatias pelo estado selvagem, não duvidou reconhecer as vantagens de substituirmos a justiça e o direito e a razão ao instinto, ao apetite e ao capricho [...]" (VARNHAGEN, 1998, P. 53).

Assim Varnhagen, vendo os índios desta forma, surpreende-se que poetas o queiram como tema de sua literatura e que filósofos o queiram como homem ideal. Com isso, não há duvida da posição do historiador Varnhagen frente à literatura que então se discutia dentro do IHGB a viabilidade de ser escrita.

Em 1856 Gonçalves de Magalhães publica o poema épico indianista $A$ Confederação dos Tamoios. Nesta obra, dedicada ao Imperador, Magalhães conta de forma poética a história de índios que se juntaram numa confederação de tribos, sob a liderança dos Tamoios, para lutar contra os colonos portugueses no século XVII. A publicação praticamente inaugura $O$ indianismo romântico, uma vez que é a primeira obra inteiramente dedicada ao tema escrita no século XIX. A repercussão de sua publicação dá inicio entre os escritores, críticos e entre membros e não membros do IHGB, à famosa polêmica em torno da Confederação dos Tamoios.

A polêmica teve como protagonistas principais dois grupos. O primeiro era aquele formado pelos defensores do poema, membros do IHGB e protegidos do Imperador, entre eles, Manuel Araújo Porto Alegre e o próprio dom Pedro II, financiador da publicação, defensor das letras pátrias e estudioso interessado nos assuntos indígenas. No decorrer da polêmica, dom Pedro II chega a pedir ao poeta português Alexandre Herculano que participasse da defesa de Magalhães, convite recusado pelo poeta. Do outro lado estavam José de Alencar e Pinheiro Guimarães. Outros ainda se manifestaram, tendo contudo, importância secundária, entre eles o Frei Francisco de Monte-Alverne, entre outros.

A polêmica em torno do poema de Magalhães mostra o grau de consciência dos diferentes agentes de produção cultural acerca do projeto de invenção histórica do Indianismo Literário. Desta forma, a discussão sobre a literatura nacional e a representação do índio nesta se dá de forma explícita, ou seja, discutia-se abertamente a viabilidade de coroar o índio como símbolo da nação.

A contenda mostra ainda, a relação estrutural de subordinação entre os campos de produção erudita e o campo de poder. Sendo assim, vemos a participação ativa do IHGB na polêmica, uma vez que seus membros dela participaram, evidenciando a influência do poder político sobre as questões culturais. Desta maneira entendemos a participação de dom Pedro II na polêmica, que era abertamente apoiador dessa forma de literatura onde o índio é tema central. 
Neste sentido, a polêmica mostra ainda, o quão hegemônico era o projeto de invenção histórica do Indianismo Literário surgido dentro do IHGB. Por conta disso, entendemos a posição de José de Alencar na polêmica. $O$ escritor é o grande crítico de Magalhães, mas suas críticas se dão em relação à forma do poema, e nunca a seu tema, o qual Alencar partilharia um ano após a polêmica com a publicação do romance indianista O Guarani.

Assim, Alencar mesmo não sendo membro do IHGB, mesmo criticando a confraria literária da qual não fazia parte, mesmo assim sua produção indianista é participante do projeto de invenção histórica do Indianismo Literário. Isto se explica pela subordinação do campo erudito (literário) ao campo de poder, uma vez que este era o responsável pela formação e consolidação de um campo de possíveis estéticos em relação ao índio. Sendo assim, José de Alencar, que buscava consagração literária, só poderia conquistá-la participando do projeto de invenção histórica do Indianismo Literário. Ao mesmo tempo, deve-se lembrar que Alencar partilhava do mesmo habitus que os outros escritores indianistas, ou seja, estava inserido no mesmo movimento estético (Romantismo), partilhava das mesmas formas de pensamento, enfim confrontava-se com o mesmo campo de possíveis estéticos.

Desta maneira, a discussão da polêmica se dá principalmente em questões de crítica literária, método literário e valor do poema como obra de arte. Com isso, as questões da forma do poema são preponderantes às questões de conteúdo. No entanto, aqui se vai analisar as questões de conteúdo do poema de Magalhães e do projeto de invenção histórica do Indianismo Literário, ou seja, pode o índio ser tema da literatura nacional?

A polêmica teve como palco principal a imprensa do período e deu-se principalmente através da publicação de artigos críticos dos diferentes participantes. Assim, a cada publicação de artigo de Alencar, vinha a resposta de algum defensor do poema. Para facilitar a compreensão do leitor, vamos apresentar os artigos de cada um deles separadamente.

José de Alencar, quando da polêmica ainda era desconhecido e não havia publicado nenhuma obra. Por conta disso, escreveu seus artigos sob o pseudônimo Ig, abreviação de Iguaçu, heroína do poema de Magalhães. Alencar era redator do Diário do Rio de Janeiro, e em suas páginas publicou seus artigos críticos, todos em forma de carta.

Em junho de 1856 José de Alencar ou Ig, publica seu primeiro artigo. Utilizando-se de vários recursos retóricos ${ }^{6}$ Ig procura todo o tempo mostrar a pobreza poética do poema de Magalhães e, para tanto, serve-se de grandes exemplos da literatura universal e inúmeros suportes teóricos para comprovar seus pontos de vista. Contudo, Alencar concorda com a idéia geral do poema:

O pensamento do poema, tirado dos primeiros tempos coloniais do Brasil, é geralmente conhecido; era um bello assumpto que, realçado pela grandeza de uma raça infeliz, e pelas scenas da natureza esplendida de nossa terra, dava thema para uma divina epopéia, se fosse escripta por Dante. (ALENCAR apud CASTELLO, 1953, p. 04).

Portanto, segundo Alencar, o passado colonial do país daria sim uma bela epopéia se fosse escrita por um grande poeta, coisa que Magalhães estava longe de ser. Dessa forma, fica clara a intenção de Alencar de obscurecer a obra de Magalhães e evidenciar sua futura produção ficcional, uma vez que um ano depois José de Alencar publica seu romance histórico indianista o Guarani, que se passa no período colonial e abusa no uso das cenas da nossa natureza e da nossa história. Assim notamos a posição de Alencar no campo literário e conseqüentemente no campo de poder e ainda sua tomada de posição estética com relação ao indígena.

Sobre a vida dos índios retratada na Confederação dos Tamoios, Alencar não vê nenhuma beleza, segundo ele: "uma página de um viajante qualquer a respeito da vida nômade dos Árabes do Deserto é mais cheia dessa poesia da liberdade selvagem do que a parte do poema a que me refiro" (ALENCAR apud CASTELLO, 1953, p. 06).

Para Alencar isso se dava porque Gonçalves de Magalhães não aproveitou o que

\footnotetext{
${ }^{6}$ Campato Junior mostra como os artigos de Alencar, escritos sob a forma de cartas, utilizava inúmeros recursos retóricos para o convencimento do publico leitor acerca de suas idéias sobre literatura e teoria literária. (CAMPATO JR, 2003)
} 
pra ele seria a idéia mais bela da pintura da vida dos índios, ou seja: "[...] o esboço histórico d'essas raças extinctas, a origem d'esses povos desconhecidos, as tradições primitivas dos indígenas, davão por si só matéria a um grande poema, que talvez um dia algum apresente sem ruído, sem aparato, como modesto fruto das suas vigílias" (ALENCAR apud CASTELLO, 1953, p. 06).

Dessa forma notamos que 0 autor corroborava alguns pressupostos do naturalista Martius, que defendia o estudo do passado de nossos índios como meio de conhecê-los melhor e dar a eles a valoração que mereciam. Para José de Alencar, esse passado serviria de tema a um grande poema, e que ele mesmo apresentaria um ano depois, sem o ruído e sem o aparato do IHGB com o qual contava Magalhães.

Na quarta carta, publicada no Diário do Rio de Janeiro em julho de 1856, José de Alencar chama a atenção para a crítica que se fazia ao Indianismo Literário, sobretudo sobre autores que inchavam os textos com termos indígenas para dar a eles certa "cor local". Segundo o autor: De ha algum tempo se tem manifestado uma certa tendência de reacção contra essa poesia inçada de termos indígenas, essa escola que pensa que a nacionalidade da litteratura esta em algumas palavras; a reacção é justa, eu também a partilho, porque entendo que essa escola faz grande mal ao desenvolvimento do nosso bom gosto litterário e artístico (ALENCAR apud CASTELLO, 1953, p. 27).

Mas Alencar não discorda da literatura indianista em si, e sim dessa produção superficial que para fazer-se nacional utiliza termos indígenas sem explorar o tema devidamente.

Para Alencar é legítima essa crítica, uma vez que o autor tinha planos de escrever uma obra indianista que explorasse a fundo a temática indígena, como fez no Guarani e em outras obras indianistas. Portanto, Alencar discorda daqueles que exageram na crítica e passam a atacar os índios, dizendo que não serviriam como tema literário, procurando lançar o ridículo e a zombaria sobre a verdadeira poesia nacional. Para José de Alencar:

Esses que assim
procedem tem uma idéa
que não posso admittir;
dizem que as raças
primitivas erão raças
decahidas, que não
tinham poesia nem
tradições; que as línguas
que fallavão eram
bárbaras e faltas de
imagens, que os termos
indígenas são mal
sonantes e pouco
poéticos; e concluem daí
que devemos ver a
natureza do Brasil com os
olhos do europeu,
exprimil-a com phrase do
homem civilisado, e
sentil-a como o individuo
que vive no doce
confortable (ALENCAR
apud CASTELLO, 1953, p.
27).

Assim, Alencar não corrobora as noções que advogam contra o índio, chamando-os de bárbaros e primitivos. Com certeza, podemos dizer que as palavras de Alencar se dirigem ao maior crítico dos índios que era também o maior apologista da civilização, o historiador Varnhagen, um dos poucos membros do IHGB a se colocar contra a produção indianista. Com isso notamos a posição de Alencar no campo literário e no campo político, ao mesmo tempo em que se torna evidente sua tomada de posição estética.

Entre julho e agosto de 1856, Manuel Araújo Porto Alegre escreve uma série de artigos em resposta às cartas de Alencar. Sem saber a identidade de Ig, Porto Alegre os publica no Correio da Tarde sob o pseudônimo "O amigo do poeta". Sendo membro do IHGB e amigo pessoal de Magalhães, Porto Alegre procura a todo custo defender a qualidade literária da Confederação dos Tamoios. Assim, os artigos do referido autor, segundo José Aderaldo Castelo "tem o valor histórico de documentar o espírito de geração ou do grupo a que se filiou o escritor, espírito dominado, entre outras coisas, pelo arrebatamento nacionalista e pela preocupação de exaltar as figuras que o integravam". (CASTELLO, 1953, p. X). O grupo ou geração a que se refere Castelo é aquele que tinha no IHGB seu local privilegiado de convivência e ação, sob a 
tutela direta do Estado Imperial, ou seja, eram membros do campo literário subordinado estruturalmente ao campo de poder.

Entretanto, as palavras de Porto Alegre revelam ainda, segundo José Aderaldo Castelo:

[...] o polemista
despeitado e mesmo
medíocre, preocupado,
no princípio, em igualar-
se em erudição e
conhecimentos artísticos
com o seu contendor,
para logo cair no
desequilíbrio e na
impaciência de quem se
sente antecipadamente
vencido, mas quer revelar
superioridade. Dominado,
porém, pelo amor próprio
que se julgava ofendido,
e pela vaidade, descamba
enfim para a linguagem
agressiva, desafiadora e
até mesmo ofensiva
(PORTO ALEGRE apud
CASTELLO, 1953, p.X).

Assim, os textos de Porto Alegre pouco valor têm na nossa discussão sobre o índio como tema literário, a não ser pelo fato de mostrar a intensidade e o tom que assumiu a polêmica. Mostrando, portanto, a posição do autor frente a invenção histórica do Indianismo Literário.

O próprio Alencar se manifesta acerca dos artigos de Porto Alegre com certo pesar, pois segundo ele, a polêmica que deveria atuar na evolução das letras do país, acaba por revelar o atraso intelectual dele. Vejamos as palavras de José de Alencar sobre o caráter que tomou a polêmica sobre a Confederação dos Tamoios:

Soffri uma decepção, a imprensa calou-se, os litteratos limitarão-se a dizer sua opinião nos diversos círculos; e apenas depois de muitos dias appareceu em um jornal uma espécie de diatribe, que devo esquecer meu amigo, por honra de nosso país e de nossa classe. Doía-me ver que a nossa civilisação estava ainda tão atrasada; pois, em vez de acceitar-se uma discussão litterária franca e leal, se

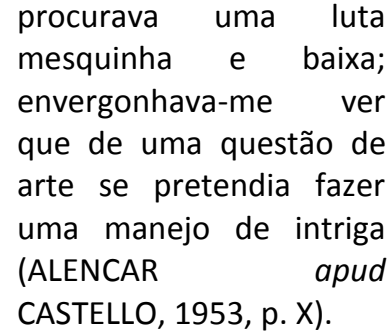

Se a polêmica tomou tal rumo, na última carta de Ig, já em agosto de 1856, José de Alencar conclui de forma categórica a questão. Segundo ele: "É preciso acabar com esta questão, e dar por uma vez como ponto decidido que a côr local, como a entendem os mestres da arte, não existe na Confederação dos Tamoyos" (ALENCAR apud CASTELLO, 1953, p. 50).

Outro participante da polêmica foi Pinheiro Guimarães. Sob o pseudônimo Omega, Pinheiro Guimarães publicou seu artigo no Diário do Rio de Janeiro em julho de 1856. O autor coloca-se em defesa de Alencar, porém, coloca-se contra a representação do índio na literatura que se queria nacional. Assim, como mostrado na epígrafe deste, Pinheiro Guimarães tinha como objetivo desmascarar a confraria literária que era - IHGB, bem como seu projeto de invenção histórica do Indianismo Literário. Com isso a posição do autor é contrária à representação do índio na literatura.

Segundo Pinheiro Guimarães, Magalhães escreveu de acordo com seu sentimento patriótico, assim como Camões. Mas se os heróis de Camões são os barões assinalados, ele se pergunta: "Quem são os heroes do Sr. Magalhães? São os Tamoyos, isto é, uma tribu de selvagens, que apenas tem de commum com os Brasileiros o terem outrora habitado uma parte do solo que estes agora occupão" (GUIMARÃES apud CASTELLO, 1953, p. 87).

Com isso, vemos que Omega não simpatiza com as tribos indígenas do país, e mais, sendo inimigos uns dos outros (portugueses e índios) desde o início do período colonial, os portugueses e agora seus filhos brasileiros não poderiam fazer uma literatura enaltecedora dos feitos dos Tamoios contra os portugueses. Portanto, para Omega: "[...] quer-se dizer que o Sr. Magalhães, Brasileiro, fez um poema patriótico, quando tomou por assumpto de seus cantos os feitos de armas mais ou menos heróicos dos Tamoyos, exercidos justamente contra os Brasileiros, ou contra seus 
ascendentes" (GUIMARÃES apud CASTELLO, 1953, p. 87).

Dessa forma, Pinheiro Guimarães não acredita que seja nacional uma literatura que fale dos primitivos habitantes do país. O autor vislumbra a tendência comum nos países de buscar suas origens reais ou imaginárias. Acredita ser legítima essa busca, no entanto, preferia que fossem outras nossas origens. Segundo o autor:

Há tempos que com profunda lastima temos vistos apparecer entre nós sérias tendências de fazerem esquecer a nossa verdadeira origem, dando-nos outras, não só falta, porém, o que mais é, muito mais baixa. Outras nações, separados do berço por um grande numero de séculos, querendo elevar-se, têm esquecido a história, e fundadas em fábulas, hão procurado para si uma origem não verdadeira, porém, sempre ilustre. Alguns de nossos patrícios, porém, querem esquecer-se de que são filhos de portuguezes, não para que à sua genealogia se vá a tronco mais nobre, mas sim para fazerem-se descendentes de Tupiniquins e Botocudos. Não lhes gabamos os gostos; antes queremos provir dos Vascos da Gama, dos Castros, do Mens de Sá, do que dos Aimbires, Jagoanharos, e de outros bárbaros mais ou menos antropophagos; não podemos chamar patrióticos os poemas que procuram sublimisar as acções d'esses gentios, em como sua guerras contra os portuguezes, quando escriptas por Brasileiros (GUIMARÃES apud CASTELLO, 1953, p. 88)

Portanto, vemos que Omega discordava não só da representação do índio na literatura romântica, mas que discordava completamente dessa busca de origens que se processava no país naquele momento, dentro desse projeto de invenção histórica do Indianismo Literário. Segundo ele, essa origem tinha de ser reconhecida nos portugueses nossos colonizadores e não em selvagens antropófagos.

Com isso, para Pinheiro Guimarães, a obra de Gonçalves de Magalhães já veio a lume condenada a perder a disputa que então se processava, uma vez que para ele os índios não serviriam como tema literário. Com isso, Alencar nada mais fez do que anunciar a derrota do poema que nasceu fadado ao insucesso. Vejamos as palavras de Omega, que concluem seu artigo:

[...] Se Sr Ig, não foi mais
que um representante da
opinião pública, elle
reuniu as diversas vozes
de reprovação espalhadas
pela cidade, englobou-as
n'uma só, e, adoçando o
que elas tinham de
áspero, tomou a bozina
da imprensa, e espalhou-
as pelo mundo. Não foi
portanto elle o campeão
que lançou por terra a
obra do Sr. Magalhães, foi
apenas o arauto que
anunciou o seu baque na
arena (GUIMARÃES apud
CASTELLO, 1953 p. 89).

Assim, segundo Pinheiro Guimarães, a invenção histórica do Indianismo Literário não era um consenso na sociedade da Corte, e mais, inúmeras vozes de reprovação se faziam ouvir a respeito. Desta forma, percebemos o indianismo mais como um projeto literário de Estado do que uma tendência espontânea surgida pela demanda do público e da população.

A ligação do Estado Imperial com o projeto de invenção histórica do Indianismo Literário torna-se ainda mais evidente quando analisamos a ativa participação do Imperador dom Pedro II, não só como membro protetor e financiador do IHGB, sendo ainda grande incentivador dos estudos etnográficos e literários, mas sobretudo pela sua ativa participação na polêmica em torno da Confederação dos Tamoios.

Em 1849, anos antes da polêmica o Imperador propõe como programa para dissertação dentro dos estudos do IHGB: "O 
estudo e imitação dos poetas românticos promove ou impede o desenvolvimento da poesia nacional?" A proposição revela o engajamento do Imperador nos assuntos literários e também o caráter oficial que assumiu o Romantismo no país. E ainda, o Imperador atuou num projeto de construir uma cultura local a este Império, buscando criar uma identidade para essa frágil e jovem monarquia tropical. Segundo Lílian Schartz:

Por meio, portanto, do financiamento direto, do incentivo ou do auxilio a poetas, músicos, pintores e cientistas, D.Pedro II tornava-se parte de um grande projeto que implicava, além do fortalecimento da monarquia e do Estado, a própria unificação nacional, que também seria obrigatoriamente cultural (SCHARTZ, 1999, p. 127).

Com isso nota-se que a participação do Imperador dom Pedro II na invenção histórica do Indianismo Literário foi ativa e substancial, atuando não só na polêmica como em todo o projeto de invenção cultural levado a cabo pelo Estado Imperial através do IHGB e outras academias culturais, tal como a Imperial Academia de Belas Artes. Ainda segundo Lílian Schartz, dom Pedro II era o chefe deste projeto de busca de originalidade cultural, assim neste momento, o Romantismo ganha status de projeto oficial do Estado Imperial, através da invenção histórica do Indianismo Literário.

Dom Pedro II publicou no Jornal do Comércio uma série de seis artigos em resposta às cartas de Ig, sob o pseudônimo "Outro amigo do poeta". Nesses artigos, o Imperador assume posição de defesa de Gonçalves de Magalhães, refazendo o caminho crítico percorrido por lg, reparando aquelas considerações que acreditava necessárias. Em carta enviada ao conselheiro Saraiva, anos depois da polêmica, dom Pedro II explicita sua posição: "[...] já eu fiz o plano de defesa do poema, [...] eu não abandono posição de defensor e elogiador [...] talvez seja ocasião de uma pena florida escrever algumas poesias fazendo realçar as belezas da Confederação [...]" (DOM PEDRO II, apud SCHARTZ, 1999, 134). Dessa forma dom Pedro II explora com afinco uma série de questões de teoria e prática literária, como questões estéticas e de vocabulário. Entretanto, nos interessa aqui suas reflexões acerca do índio e de seu papel na literatura romântica que então se escrevia. Segundo José Aderaldo Castelo, uma série de fatores levaram dom Pedro II a essa postura frente à polêmica:

[...] a amizade dedicada a Magalhães, o fato de ter sido o patrocinador da edição do poema, a sua posição de protetor das letras no Brasil, seu sincero desejo de ver o país ilustrado, os efeitos da onda nacionalista, que impedia o rigoroso juízo dos nossos verdadeiros valores em todos os setores da atividade nacional, fizeram com que ele insistisse na beleza e valor literário do poema (CASTELLO, 1953, p. XI)

Vê-se aí então o quão profunda era a ligação do Imperador com as letras do país, sua ativa participação nos assuntos culturais nacionais através do IHGB e ainda, seu papel preponderante no processo de invenção histórica do Indianismo Literário.

No primeiro dos artigos, publicado em agosto de 1856, dom Pedro II começa fazendo reparações nas considerações de Alencar, sobretudo no concernente à pintura da vida dos índios e da história primitiva destes, que segundo Ig foi mal desenvolvida por Magalhães. Para o Imperador:

A pintura da vida dos índios não existe neste canto, encontra-se na maior parte delles, e no quarto apresenta o autor o esboço histórico, assim como as tradições primitivas de que fala o crítico, agora só trata o poeta do estado de escravidão a que foram reduzidos os índios, dispondo assim o leitor para tomar o maior interesse pela causa que defende $o$ heroe do poema; os bellíssimas 
comparações da andorinha presa e do guará merecião ser citadas. (DOM PEDRO II apud CASTELLO, 1953, p. 94)

Assim, para o Outro amigo do poeta, Magalhães não só fez o esboço histórico da vida dos índios, mas também o fez acerca das tradições primitivas destes. $\mathrm{E}$ mais, mostrou $\mathrm{O}$ estado de escravidão a que foram reduzidos, chamando a atenção dos leitores para a causa que defende o herói do poema, ou seja, a luta dos índios contra os invasores portugueses.

E na continuação do artigo, dom Pedro II pergunta-se: "Por que teve lugar a confederação dos Tamoyos? Não foi para livrar a pátria da escravidão imposta por outra raça?"(DOM PEDRO II apud CASTELLO, 1953, p. 94). Desta maneira, vemos que o Imperador concordava com 0 levante dos índios contra os portugueses. Assim, o Imperador não só considerava legítima a luta dos índios contra seus ascendentes, como considerava importante que essa resistência fosse lembrada e enaltecida de forma poética dentro da literatura nacional. E ainda, o Imperador considerava sinal de patriotismo a busca de nossas origens primitivas em detrimento das origens portuguesas, busca anteriormente criticada por Pinheiro Guimarães.

Nas considerações acerca da quarta carta de Ig, dom Pedro II entra na questão acerca do emprego de palavras indígenas para a composição literária. Ele próprio estudou o Tupi e - Guarani como forma de incentivar o Movimento Romântico. Segundo o Outro amigo do poeta, Magalhães não torna sua poesia nacional apenas pelo emprego de algumas palavras tupis, as quais segundo ele, não se pode desprezar para a composição literária. Assim, a idéia seria unir os dois sistemas para a feitura da literatura nacional, ou seja, utilizar as tradições e costumes indígenas como tema literário, sem esquecer o uso de palavras indígenas nessa composição. Desta forma, lembrando que outros já o tinham feito, o Imperador defende o uso feito por Magalhães destas tradições para a composição da Confederação dos Tamoios. Vejamos as palavras do monarca amigo das letras:

Assim como outros já o tinham feito, aproveitou - Sr. Magalhães das tradições e costumes índios o que há de mais notável, não formando delles episódios importantes senão quando exige a necessidade de dar energia à ação principal, ou a pintura do heroe que a symbolisa, como, por exemplo, na scena do hymno guerreiro e na da targapema, em que tanto sobresahe a fortaleza do caracter de Aimbire (DOM PEDRO II apud CASTELLO, 1953, p. 95).

Dessa forma, o Imperador dom Pedro II não só concorda com o uso dos costumes e das tradições indígenas, como acredita que os feitos dos índios na confederação, narrada no poema de Gonçalves de Magalhães, revela o caráter firme e nobre que tinham esses índios lutando pela sua liberdade e seus modos de vida contra o invasor europeu. E concluindo o primeiro e mais importante de seus artigos, dom Pedro II pede que na sua ação reconheçam o valor do poema: "[...] o reconhecimento do mérito real do poema, depois que este for lido com calma, será o único elogio completo do poeta e da aç̧ão praticada pelo monarca amigo das letras" (DOM PEDRO II apud CASTELLO, 1953, p. 102).

Quatro anos depois, na carta já citada do Imperador a seu conselheiro, dom Pedro II escreve a respeito de Ig: "[...] não queria que o Ig se empavonasse mais descobrindo um único adversário [...] quanto a ele, ou se entra no grupo, ou se esta fora [...]" (DOM PEDRO II, apud SCHARTZ, 1999, p. 134). Com efeito, Alencar já havia publicado o Guarani, mesmo assim não entrou para o grupo de escritores do IHGB, mas sua obra entrou para o projeto de invenção histórica do Indianismo Literário.

Outros autores participaram da polêmica sobre a Confederação dos Tamoios. Alguns deles, seguindo o exemplo de Porto Alegre, desviaramse da questão principal e em seus artigos encontra-se mais censuras ou elogios a este ou aquele contendor. Dessa forma, não possuindo valor literário, servem apenas para mostrar o calor da polêmica, as posições frente ao projeto de invenção do Indianismo Literário, evidenciando ainda o atraso intelectual de que se queixou José de Alencar.

As concepções de Varnhagen acerca dos povos indígenas não foram aceitas tacitamente, 
sem contestação dentro do Instituto Histórico e Geográfico Brasileiro. Em 1860, Gonçalves de Magalhães, escritor indianista e membro atuante dentro dos estudos do IHGB, publica na revista do Instituto o artigo. Os indígenas do Brasil Perante a História, depois de um pedido direto do Imperador dom Pedro II.

Neste artigo, Gonçalves de Magalhães faz um minucioso estudo da história e sobretudo da etnologia indígena, provando com exemplos tirados destes campos de conhecimento, que os índios estavam longe de serem os seres decadentes como acreditava Varnhagen. A idéia era "mostrar esse elemento tal como elle é, ou ao menos tal como se nos apresenta; rehabilital-o aos olhos da philosophia e da história, é o fim a que agora me proponho [...]" (MAGALLHÃES, 1860, p. 06). O texto está, portanto, carregado de representações indianistas, que enaltecem os indígenas com o intuito de atingir o fim proposto pelo artigo e que configuram também um campo de possíveis estéticos sobre o índio. O artigo mostra ainda a posição de Magalhães com relação ao Indianismo Literário, bem como sua posição no campo literário e conseqüentemente no campo de poder.

Segundo Gonçalves de Magalhães, Varnhagen na sua obra História Geral do Brasil, reuniu e abonou todas as acusações que tem sido feitas contra os nossos selvagens em páginas diversas, "concedendo-Ihes apenas insignificantes virtudes". Para Magalhães, J.J. Rousseau escreveu seu discurso, para evitar essa indiferença pelo indígena e para provocar o barulho da crítica. Com isso, o autor clama a Varnhagen que: "Com os ouvidos do philosopho de Genebra, ouça o autor da 'História Geral do Brasil' o pequeno ruído da nossa voz, e consinta de bom grado que a elle nos acostemos, para dar vida e actualidade às nossas reflexões". (MAGALHÃES, 1860, p. 08).

Com isso, Magalhães propunha que se visse os índios com esses olhos da filosofia de Rousseau, ou seja, queria que Varnhagen visse as virtudes dos índios naquilo que eles são de fato, ou seja, homens primitivos, próximos à natureza. Desta forma, eles têm de ser vistos considerando essa especificidade. As palavras de Magalhães evidenciam ainda a influência da filosofia de Rousseau na forma de se ver o índio e conseqüentemente na forma de representá-lo, uma vez que esses preceitos filosóficos atuaram como conceitos formadores do indianismo e conseqüentemente do Indianismo Literário.
No seu artigo, Magalhães escolheu alguns pontos do texto de Varnhagen para contestação. O texto é longo e discute inúmeros detalhes, como por exemplo, a alcunha "indígena" dada aos índios, preceitos religiosos dos mesmos, organização social, entre outros.

Gonçalves de Magalhães, sendo estudioso interessado pela etnografia indígena e escritor indianista, nutria uma profunda simpatia e até mesmo admiração pelos povos indígenas. Para o autor, os índios têm de ser vistos na sua peculiaridade para assim entendermos seu caráter e sua verdadeira natureza. Para Magalhães:

O homem mesmo
selvagem não deixa por
isso de ser ente racional e
moral; em sua alma, bem
como em seu corpo,
existem todos os
attributos naturaes que o
constituem nosso irmão;
se lhe falta nesse estado
o desenvolvimento da
intelligencia nas sciencias
e nas artes, e algumas
grandes virtudes, raros
dotes de bem poucos
entre os povos civilisados,
em compensação porem
o não mancham grandes
vícios e crimes que entre
esses se observam; por
que a cultura desenvolve
tudo, o bom e o mao, a
virtude e o vicio. Oxalá
assim não fosse!
(MAGALHÃES, 1860, p.
28)

Com isso Magalhães faz a defesa dos povos selvagens, chegando a construir uma representação indianista destes. E com os olhos do filósofo de genebra, o autor propaga a idéia de que a cultura, ou seja, a civilização desenvolve tudo, inclusive as virtudes e os vícios. $E$ se os índios são primitivos, ao menos seu caráter não foi perdido para a civilização corrompida.

Sendo filho desta civilização, Gonçalves de Magalhães diz que não pode concordar inteiramente com Rousseau, no entanto e nem por isso pode concordar com o historiador defensor do estado civilizado. Vejamos as palavras do poeta Magalhães:

$$
\text { Filho da civilisação, }
$$


maravilhas, gozando dos seus dons, nem por pensamento, nem por zombaria pretendo imitar o philosopho de Genebra, nesse seu discurso em favor do estado selvagem, verdadeiro brinco de uma imaginação caprichosa [...]. Mas por amor dessa civilisação mal definida, que é o ídolo do nosso historiador, não irei quase ao ponto de accusar a Providência de haver abandonado a espécie humana só a mercê de instinctos ferozes, dizendo como elle 'sem os vínculos das Leis e da religião o triste mortal propende tanto à ferocidade que quase se metamorphosea em fera' (MAGALHÃES, 1860, p. 30-31).

Desta maneira, Magalhães coloca-se não como defensor do estado primitivo em detrimento do estado civilizado, mas coloca-se em defesa dos povos indígenas que têm sido pintados com as cores erradas pelo historiador Varnhagen. Segundo ele, seria injusto dizer como alguns escritores que os índios: "eram falsos, infiéis, desconfiados e nenhuma idéia tinham de sã moral". Pelo contrário, segundo Magalhães os índios tinham uma "Hospitalidade e generosidades sem limites até para o inimigo, [...] tão patriarcal costume si não era um preceito de sua religião, a que jamais faltaram, si não era a manifestação espontânea da bondade de seus corações" (MAGALHÃES, 1860, p. 28).

Com as concepções de Varnhagen sobre os índios, que tão pouca simpatia tinha por povos que não tinham leis escritas, não possuíam organizações sociais complexas, não tinham uma religião institucionalizada, Magalhães não se admira que o historiador:

[...] não saiba por que há poetas, e até philosophos que às vezes fazem a satyra da civilisação, descobrindo algumas virtudes no estado selvagem, nem que por isso vejam nesse estado a maior felicidade humana. Os brocados da civilisação encobrem muitas misérias, e a pouco chegam; e prestam-se mais à sátira do que a pobreza do selvagem. (MAGALHÃES, 1860, p. 31).

Com essas declarações de Magalhães, vemos o quão evidente estava a discussão em torno da literatura indianista. Notamos que o poeta escreve seu texto não só para contestar as concepções de Varnhagen acerca dos povos indígenas, mas para fazer a defesa destes e consequentemente justificar a produção literária indianista. Se os índios estavam longe de ser os homens ferozes de Varnhagen, se possuíam inúmeras virtudes e qualidades específicas de sua condição selvagem, se eram os verdadeiros indígenas, habitantes primitivos da nação, obviamente que teriam seu lugar garantido na produção literária, sendo coroados como o símbolo máximo da nacionalidade brasileira.

Por fim, Magalhães acredita que não devemos desconhecer a importância dos índios na população do Brasil, e não devemos acusá-los de defender suas terras frente à invasão dos portugueses. Segundo ele, os índios apenas retribuíram o mau com o mau, e se lutaram e mataram para defender sua vida e liberdade, a Justiça estará ao lado deles em detrimento dos portugueses, invasores e escravizadores que matavam simplesmente por ganância. Daí a relevância dos índios para a população do Brasil e principalmente para a sua literatura que se queria nacional e nacionalista. Concluamos com o poeta Gonçalves de Magalhães: "Por isso é que os feitos dos indígenas offerecem argumento sympathico à nossa poesia nacional. E como bem notou o Sr. Odorico Mendes: os selvagens, rudes e de costumes quasi homéricos, podem prestar belos quadros à epopéia" (MAGALHÃES, 1860, p. 63).

Para concluir, notamos que a literatura indianista constitui-se em projeto de Estado. Dada as ligações do campo literário com o campo de poder, percebemos claramente a influência deste sobre aquele. Com isso, vemos escritores românticos, ligados ao Estado Imperial através do IHGB, produzindo uma literatura engajada no projeto Imperial de constituição de uma cultura local. Desta forma, o Indianismo Literário configura-se como uma invenção histórica levada 
a cabo pelo IHGB e pela elite cultural da Corte, através de suas ligações com o Estado Imperial.

\section{REFERÊNCIAS}

BOURDIEU, Pierre. As Regras da Arte: Gênese e estrutura do campo literário. São Paulo: Companhia das Letras, 1996.

CASTELLO, José Aderaldo (org.) A Polêmica sobre a Confederação dos Tamoios. São Paulo: FFLCHUSP, 1953.

CAMPATO JR, João Adalberto. Retórica e Literatura: O Alencar polemista nas cartas sobre a Confederação dos Tamoios. São Paulo: Scortecci Editores, 2003.

MARTHIUS, CFD Von. Como se deve escrever a história do Brasil. O Estado de Direito entre os Autóctones do Brasil. Belo Horizonte:Itatiaia/São Paulo: Edusp, 1981.

ODÁLIA, Nilo (Org). Varnhagen. São Paulo: Ática, 1979. Col. Grandes cientistas sociais.

SCHARTZ, Lílian M. As Barbas do Imperador. São Paulo: Companhia das Letras, 1999.

VARNHAGEN, Franscisco Adolfo de. Florilégio da Poesia Brasileira; ou, Collecção das mais notáveis composições do poetas brazileiros falecidos, contendo as biographias de muitos delles, tudo precedido de um ensaio histórico sobre as lettras no Brazil. Lisboa: Imp. Nacional/Madri: Imp. Da V.D.R.J. Dominguez, 1850/1853. 3 v.

VARNHAGEM, Francisco Adolfo de. Como se deve entender a nacionalidade na história do Brasil. Anais do Museu Imperial, Petrópolis, n.9, p.53, 1998.

\section{FONTES}

REVISTA NITHEROY, Paris, v.1, n.1, 1836.

REVISTA DO INSTITUTO HISTÓRICO E GEOGRÁFICO BRASILEIRO. Rio de Janeiro, 18381860. 